\title{
qPCR Assays for the Detection of Cylindrocladium buxicola in Plant, Water, and Air Samples
}

B. Gehesquière, Plant Sciences Unit-Crop Protection, Institute for Agricultural and Fisheries Research (ILVO), Burg. Van Gansberghelaan 96 bus 2, 9820 Merelbeke, Belgium, and Laboratory of Phytopathology, Department of Crop Protection, Faculty of Bioscience Engineering, Ghent University, Coupure links 653, 9000 Ghent, Belgium; S. D'Haeyer, Plant Sciences Unit-Crop Protection, ILVO; K. T. K. Pham and A. J. Van Kuik, Applied Plant Research, Wageningen UR, Prof. van Slogterenweg 2 P.O. Box 85, 2160 Lisse, The Netherlands; M. Maes, Plant Sciences UnitPlant Sciences Unit-Crop Protection, ILVO; M. Höfte, Laboratory of Phytopathology, Department of Crop Protection, Faculty of Bioscience Engineering, Ghent University; and K. Heungens, Plant Sciences UnitPlant Sciences Unit-Crop Protection, ILVO

\begin{abstract}
Gehesquière, B., D'Haeyer, S., Pham, K. T. K., Van Kuik, A. J., Maes, M., Höfte, M., and Heungens, K. 2013. qPCR assays for the detection of Cylindrocladium buxicola in plant, water, and air samples. Plant Dis. 97:1082-1090.

Cylindrocladium buxicola (syn. C. pseudonaviculatum; teleomorph Calonectria pseudonaviculata) is an important fungal pathogen of Buxus spp. Although widespread in Western Europe, this pathogen has only recently been introduced into North America, where it represents a significant threat to the U.S. and Canadian boxwood industries. Trade of latently infected nursery stock is an important mode of longdistance dissemination and introduction of this pathogen but no methods for detection of latently infected material are available. Also, the pathways for short-distance dispersal of C. buxicola have not been adequately studied. Improved detection methods of this pathogen in air and water samples would benefit future research in this area. We have developed real-time polymerase chain reaction assays for the detection of $C$. buxicola based on the ribosomal DNA internal transcribed spacer 1 (ITS) and the $\beta$-tubulin 2 gene (TUB). Using a TaqMan probe conju-

ITS-based assay could reliably detect as little as $10 \mathrm{fg}$ of genomic DNA or 20 copies of cloned target DNA and was approximately 70 times more sensitive than the SYBR Green TUB-based assay. The ITSbased assay provided good but not complete specificity, and is well suited for epidemiological studies. The TUB-based assay, however, proved to be fully specific and can be used for diagnostics. We developed and optimized sample processing and DNA extraction methods for detection of latently present $C$. buxicola in boxwood plants and quantification of conidia in water and air samples. C. buxicola could be detected in $20 \mathrm{~g}$ of plant material, of which only $1 \mathrm{ppm}$ of the tissue was infected, in 10-ml water samples containing as low as 1 conidium/ $\mathrm{ml}$, and on Melinex tape pieces representing $12 \mathrm{~h}$ of air sampling containing 10 or more conidia. The applicability of the techniques to plant, water, and air samples of practical size was demonstrated.
\end{abstract} gated with a $3^{\prime}$ minor groove binding group (TaqMan MGB probe), the
Buxus spp., commonly known as boxwood or box plants, are broad-leaved evergreen shrubs ranging from compact and slowgrowing to relatively tall habits with an open canopy. This diversity makes them popular for a wide range of ornamental landscaping uses. Boxwood plants may be used as individual specimens or in hedges, parterres and groups. Special uses include growth in containers and as topiary plants $(3,4,36,45)$. For a long time, boxwood was considered to be generally free of important pests and diseases (30). In the mid-1990s, however, a formerly unknown blight disease on Buxus was observed in the United Kingdom, caused by the new species Cylindrocladium buxicola Henricot 2002 (syn. C. pseudonaviculatum Crous, J.Z. Groenew. \& C.F. Hill 2002; teleomorph Calonectria pseudonaviculata) $(28,29)$. In 1998, similar symptoms of blight on Buxus were reported in New Zealand but $C$. buxicola was misidentified as $C$. spathulatum or possibly $C$. ilicicola $(28,41)$.

Since the observations in the United Kingdom and New Zealand during the 1990s, the pathogen has spread throughout Europe, probably via the movement of infected nursery stock $(33,42)$. $C$. buxicola has been consecutively confirmed in Belgium (15), the Netherlands (12,30), Germany (9), France (43), Ireland (12,33), Italy (42), Switzerland (47), Slovenia (5), Spain (46), Croatia (13),

Corresponding author: K. Heungens,

E-mail: kurt.heungens@ilvo.vlaanderen.be

Accepted for publication 14 February 2013.

http://dx.doi.org/10.1094/PDIS-10-12-0964-RE

(C) 2013 The American Phytopathological Society
Austria (22,33), the Czech Republic (23), Denmark (26), the Republic of Georgia (25), and Turkey (1). In October 2011, boxwood blight was first detected in North Carolina and Connecticut in the United States. Subsequent monitoring resulted in the observation of the disease in several more locations in the United States and Canada $(18,33,39)$. The U.S. findings include the two major production areas for boxwood, as described by Bir et al. (6), which illustrates the potential threat to the North-American boxwood industry. C. buxicola can seriously affect the aesthetics of the host plants $(21)$, often making them unmarketable $(33,42)$. Symptoms include dark-brown, often pale-centered leaf spots and characteristic black streaks on the young stems. The disease eventually leads to severe defoliation, dieback, and sometimes even plant mortality. Having been observed in historical gardens throughout Europe (26) and isolated from wild Buxus populations in the United Kingdom (27), the Republic of Georgia (25), Turkey (1), Belgium, and Germany (B. Gehesquière and K. Heungens, unpublished data), $C$. buxicola also threatens historically and culturally important sites and native boxwood populations and habitats.

Trade of latently infected nursery stock is an important pathway of long-distance dissemination and introduction of this pathogen on a national (27), international (42), and even intercontinental scale, as demonstrated by the recent introduction of $C$. buxicola into North America. Maximizing the efficacy of cultural and chemical control and eradication measures depends on a profound understanding of human-mediated and natural pathways of spread (30). Henricot (27) suggested that primary infection occurring from windborne conidia was unlikely, because the conidia are sticky. Short-distance dispersal was suggested to occur via water (splashing water, runoff water, or in wind-driven rain), contaminated tools, and animals such as birds and insects $(27,33)$; how- 
ever, these claims have not been substantiated by scientific research. In addition to the ambiguities regarding the possible pathways of spread, no data are available on the relative importance of each pathway, their correlation with weather conditions, and the distances over which they can occur.

To unravel the characteristics of the spread of $C$. buxicola, one must be able to detect small amounts of the fungus in plant and environmental samples of practical size. Real-time polymerase chain reaction (PCR), also known as quantitative (q)PCR, allows for fast detection of particular DNA sequences in complex samples with unprecedented accuracy, reliability, and sensitivity (34). In addition to superior sensitivity, qPCR allows for quantification of the amount of DNA (34), making it a popular molecular tool for pathogen detection and quantification $(2,19,20,31)$. Most of the qPCR protocols use primers based on the DNA sequences of the internal transcribed spacer regions of the ribosomal RNA genes (ITS) or the variable region 1 of the $\beta$-tubulin 2 gene (TUB). These sequences are the most widely available among different organisms in public databases such as GenBank, allowing design of primers without the need to sequence a large collection of non-target organisms (2). In fungi, ITS sequences tend to have less interspecific variability than TUB sequences $(37,49)$, possibly hampering the development of species-specific primers. On the other hand, whereas TUB genes are single-copy, ITS sequences tend to be present in multiple copies per genome $(7,8,49)$, which increases the sensitivity of detection.

In this research, we have developed qPCR primers and probes for both the ITS region and the TUB gene. The sensitivity and specificity of the best qPCR assays were compared and the data were used to estimate the ITS copy number. Second, we evaluated and selected the most optimal sample processing and DNA extraction methods that, in combination with the qPCR assays, allow reliable quantification of the pathogen in plant, air, and water samples of practical size.

\section{Materials and Methods}

Fungal isolates and DNA extraction. The name, host, and origin of all isolates used in the development of the qPCR assays are listed in Table 1. The non-C. buxicola isolates were selected based on their ITS sequence similarity to $C$. buxicola or their potential presence in the same ecological niche. For regular DNA extractions, fungal isolates were grown for 3 days at $20^{\circ} \mathrm{C}$ in $20 \mathrm{ml}$ of V8 juice broth in sterile 50-ml Falcon tubes (Corning Life Sciences), centrifuged for $5 \mathrm{~min}$ at 6,800 rcf, and washed twice with sterilized MilliQ water. Genomic DNA (gDNA) was extracted from 50 to $100 \mathrm{mg}$ of mycelium that had been vacuum dried over a sterile filter. Conidial suspensions of $C$. buxicola isolate CB002 were obtained by rinsing 14-day-old cultures on potato carrot agar with chloramphenicol (carrot pieces, $20 \mathrm{~g} /$ liter; potato pieces, 20 $\mathrm{g} / \mathrm{liter}$; agar, $20 \mathrm{~g} / \mathrm{liter}$; and chloramphenicol, $100 \mathrm{mg} / \mathrm{liter}$ ) with a $0.1 \%$ Tween 20 (Sigma-Aldrich) solution and rubbing the surface with a glass rod. The conidial suspensions were filtered using a $125-\mu \mathrm{m}$ sieve (Fritsch). Concentrations of conidia were determined using a hemocytometer.

To determine the optimal methods for DNA extraction from fungal mycelium, $C$. buxicola conidia (water and air samples), and $C$. buxicola-infected plant material (plant samples), the efficiency of the following commercially available DNA extraction kits was compared: QuickPick SML Genomic DNA (Bio-Nobile), QuickPick SML Plant DNA (QPP kit; Bio-Nobile), Invisorb Spin Plant mini kit (ISP kit; STRATEC Molecular), DNeasy plant mini kit (DP kit; Qiagen), and the PowerSoil DNA isolation kit (PS kit; Mo Bio Laboratories). The best DNA extraction method for each purpose was selected based on these criteria: target DNA yield, the successful removal of PCR-inhibiting compounds, and the cost of material and labor. DNA concentration in the samples was quantified using a Nanodrop ND-1000 spectrophotometer (Isogen Life Science) and DNA samples were stored at $-20^{\circ} \mathrm{C}$ until further use.

PCR amplification, cloning, and sequencing. The TUB and ITS regions were PCR-amplified using the primers T1/T2 (40) and ITS1/ITS4 or ITS1F/ITS4 $(24,49)$, respectively. Conventional PCR reactions were performed in a GeneAmp PCR System 9700 PE (Life Technologies Europe), in 50- $\mu$ l reactions containing 50 to $100 \mathrm{ng}$ of target gDNA, $0.3 \mu \mathrm{M}$ each primer, and $1 \times$ DreamTaq PCR Master mix (Fermentas Belgium). After 5 min of initial preheating at $94^{\circ} \mathrm{C}, 35 \mathrm{PCR}$ cycles of $30 \mathrm{~s}$ of denaturation at $94^{\circ} \mathrm{C}, 30$ $\mathrm{s}$ of annealing at $55^{\circ} \mathrm{C}$, and $45 \mathrm{~s}$ of extension at $72^{\circ} \mathrm{C}$ were performed. The reactions ended with a final extension at $72^{\circ} \mathrm{C}$ for 10 min. The amplified fragments of expected size were purified with the Nucleospin Extract II purification kit (Macherey-Nagel) and sequenced at Macrogen. In total, DNA sequences were determined in a collection of $30 \mathrm{C}$. buxicola isolates originating from 11 countries (data not shown). Three C. buxicola strains (CB002, CB045, and RHS PT25; Table 1) were selected as reference isolates, because their ITS and TUB fragments were representative for the collection (B. Gehesquière and K. Heungens, unpublished data). The ITS and TUB sequences of reference isolate $C$. buxicola CB002 were cloned into the PCRII-TOPO vector with the TOPO TA cloning kit (Life Technologies Europe) following the manufacturer's instructions. DNA of the plasmid clones (pDNA)

Table 1. Identity, host, country of origin (Country), and isolation year (Year) of the isolates used

\begin{tabular}{|c|c|c|c|c|c|c|c|}
\hline \multirow[b]{2}{*}{ Organism } & \multirow[b]{2}{*}{ Isolate code } & \multirow[b]{2}{*}{ Host origin } & \multirow[b]{2}{*}{ Country } & \multirow[b]{2}{*}{ Year $^{x}$} & \multicolumn{2}{|c|}{ GenBank accession number ${ }^{w}$} & \multirow[b]{2}{*}{ Source $^{y}$} \\
\hline & & & & & ITS & TUB & \\
\hline Cylindrocladium buxicola & CB002 & Buxus sempervirens & Belgium & 2007 & JX535321 & JX535307 & ILVO \\
\hline C. buxicola & CB045 & B. sempervirens & Germany & 2009 & JX535322 & JX535308 & ILVO \\
\hline C. buxicola & RHS PT25 & B. sempervirens & United Kingdom & 2006 & JX535323 & JX535309 & 30 \\
\hline C. colhounii & Ccol001 & Rhododendron sp. & Belgium & 2010 & JX535314 & JF802784 & 32 \\
\hline C. parasiticum & Cpara002 & Guzmania sp. & Belgium & 2010 & JX535313 & JX535301 & ILVO \\
\hline C. pauciramosum & Cpauc001 & Azalea indica & Belgium & 2009 & JX535312 & JX535324 & ILVO \\
\hline C. scoparium & Cscop001 & Rosa sp. & Belgium & 2011 & NA & JX535299 & ILVO \\
\hline Aspergillus westerdijkiae & ASP & C. аппиит & Belgium & 2007 & JX535320 & JX535306 & ILVO \\
\hline Botrytis cinerea & PCF1080 & Fragaria $\times$ ananassa (Duch.) & Belgium & 2007 & JX535319 & JX535305 & RSF \\
\hline Cladosporium halotolerans & CLA & Air sample & Belgium & 2011 & JX535318 & JX535304 & ILVO \\
\hline Colletotrichum acutatum & PCF721 & Fragaria $\times$ ananassa (Duch.) & Belgium & 2008 & JX535317 & NA & 19 \\
\hline Fusarium oxysporum & PSKW2 & Capsicum аппиит & Belgium & 2007 & JX535310 & JX535298 & ILVO \\
\hline Penicillium chrysogenum & KVP201 & Air sample & Belgium & 2011 & JX535315 & JX535302 & ILVO \\
\hline Trichoderma sp. & TRI & NA & Belgium & 2007 & JX535316 & JX535303 & ILVO \\
\hline Verticillium nonalfalfae ${ }^{\mathrm{z}}$ & VA1 & Solanum lycopersicum & The Netherlands & NK & AF364014 & DQ840616 & 14 \\
\hline V. dahliae & Ve005 & Soil sample & Belgium & 2004 & GQ495791 & GU564541 & 20 \\
\hline Volutella buxi & VB005 & B. sempervirens & Belgium & 2009 & JX535311 & JX535300 & ILVO \\
\hline
\end{tabular}

\footnotetext{
${ }^{\mathrm{w}}$ ITS = ribosomal DNA internal transcribed spacer region, TUB $=\beta$-tubulin 2 gene, and NA $=$ data not available.

${ }^{\mathrm{x}} \mathrm{NK}=$ not known.

y ILVO = Institute for Agricultural and Fisheries Research, Merelbeke, Belgium and RSF = Research Station for Fruit Growing, Sint-Truiden, Belgium.

${ }^{\mathrm{z}}$ Reclassified from V. albo-atrum following Inderbitzin et al. (31).
} 
was extracted using the NucleoSpin plasmid DNA purification kit (Macherey-Nagel). pDNA containing target ITS and TUB sequences were denoted $\mathrm{pDNA}_{\mathrm{ITS}}$ and $\mathrm{pDNA}_{\mathrm{TUB}}$, respectively. The plasmid inserts were sequenced by Macrogen using primers SP6 and T7 to confirm that the target fragments were correctly amplified and cloned. The copy number of plasmids and, thus, the number of templates in a specific PCR reaction was calculated based on the molecular weight of the plasmids and the DNA concentration in the plasmid solution as described by Whelan et al. (48).

Design of real-time PCR primers, TaqMan probes, and qPCR assays. To develop specific qPCR primers for $C$. buxicola, ITS and TUB sequences of $C$. buxicola isolates were aligned with the GenBank sequence data of closely related Cylindrocladium spp. Regions that were conserved within the C. buxicola isolates but differed from the other Cylindrocladium spp. were used for selecting candidate primer pairs and TaqMan probes using the oligo design tool AlleleID (PREMIER Biosoft) and through manual inspection of the multiple alignment. Combinations of 13 candidate ITS-based primers and 2 ITS-based TaqMan minor groove binding (MGB) probes as well as combinations of 12 candidate TUB-based primers were subjected to preliminary sensitivity and specificity tests via amplification and melting-curve analysis of qPCR reactions, with 10-fold dilution series of gDNA of three fungal isolates (CB002, VB005, and Cpauc001) as templates. Primers were synthesized by Isogen Life Science and the TaqMan MGB probes by Life Technologies Europe.

The qPCR reactions were performed in 25 - $\mu$ l volumes containing gDNA or pDNA template, $0.3 \mu \mathrm{M}$ each primer (see Results section), and Maxima SYBR Green/ROX qPCR Master Mix (Fermentas Belgium) (hereafter referred to as SYBR Green MM). When TaqMan technology was used, the reactions contained the same concentrations of DNA and primers, with the addition of 0.2 $\mu \mathrm{M}$ probe MGB539 and the use of Maxima Probe/ROX qPCR Master Mix (Fermentas Belgium) (hereafter referred to as Probe MM) instead of the SYBR Green MM. Amplification and detection of fluorescence were performed in Framestar 96 semi-skirted PCR plates with black frames and white wells (4titude) using an ABI Prism 7900 HT (Life Technologies Europe).

The thermocycling profile for the $\mathrm{qPCR}$ reactions in SYBR Green MM consisted of $2 \mathrm{~min}$ preheating at $50^{\circ} \mathrm{C}, 10 \mathrm{~min}$ at $95^{\circ} \mathrm{C}$, and 40 cycles of $15 \mathrm{~s}$ of denaturation at $95^{\circ} \mathrm{C}$ and $60 \mathrm{~s}$ of annealing or extension at $60^{\circ} \mathrm{C}$. Melting curve analysis was used to confirm the selectivity of the amplicons. For reactions using a TaqMan probe construct, the annealing temperature $\left(\mathrm{T}_{\mathrm{a}}\right)$ was adjusted to optimize sensitivity and specificity.

For quantification, standard curves were constructed by including reactions containing 10 -fold dilution series of pDNA or gDNA of reference strain CB002 per reaction $\left(10^{6}\right.$ to $10^{2}$ copies or fg per reaction) to each qPCR run. No-template control (NTC) reactions were included in which the DNA was substituted with MilliQ water. The manufacturer's Sequence Detection System (Life Technologies Europe) was used to generate the amplification curves for each reaction. The threshold cycle values $(\mathrm{Ct})$ were determined at a $\Delta \mathrm{Rn}$ of 0.1 .

Validation of specificity, sensitivity, and intra- and inter-assay variance. For the most optimal ITS construct, $\mathrm{T}_{\mathrm{a}}$ was optimized for specificity and sensitivity. Three TaqMan qPCR series were performed, following the same thermocycling profile as listed above but at a $\mathrm{T}_{\mathrm{a}}$ of 60,62 , or $64^{\circ} \mathrm{C}$. Each PCR series consisted of three replicate reactions containing $100 \mathrm{pg}$ of gDNA of the selected $C$. buxicola reference strains and $100 \mathrm{pg}$ of gDNA of all non- $C$. buxicola isolates listed in Table 1 . The $\mathrm{T}_{\mathrm{a}}$ resulting in the best combination of sensitivity and specificity was selected for further use in qPCR reactions containing TaqMan technology. Additionally, a SYBR Green qPCR reaction series was conducted at a $\mathrm{T}_{\mathrm{a}}$ of $60^{\circ} \mathrm{C}$ to test the specificity of the most optimal TUB construct.

The intra-assay variance (repeatability) and the inter-assay variance (reproducibility) of the optimal ITS construct was determined in three independent $\mathrm{qPCR}$ reaction series, each containing six replicate 10 -fold dilution series of gDNA and $\mathrm{pDNA}_{\text {ITS }}\left(10^{6}\right.$ to $10^{2}$ fg of gDNA or pDNA ${ }_{\text {ITS }}$ copies). To assess the sensitivity of the ITS construct at lower DNA concentrations, the detection threshold for gDNA and pDNA ${ }_{\text {ITS }}$ was determined in a qPCR assay using six replicate dilution series of gDNA $(1,000,200,100,50,20$, and 10 fg) and $\mathrm{pDNA}_{\text {ITS }}\left(1,000,200,100,50,20\right.$, and $10 \mathrm{pDNA}_{\text {ITS }}$ copies). The lowest concentrations of gDNA and $\mathrm{pDNA}_{\mathrm{ITS}}$ at which all six technical replicates were detected were defined as reliable limits of detection (LODs).

Estimation of ITS copy number. The ITS copy number was estimated by comparing the difference in the $\mathrm{Ct}$ values $\left(\Delta \mathrm{Ct}_{\mathrm{gen}}\right)$ between the linear regression curves obtained after real-time SYBR Green amplification of the single-copy TUB and the multi-copy ITS using the same two replicate dilution series of gDNA $\left(10^{6}\right.$ to $10^{2} \mathrm{fg}$ ) and the most optimal TUB and ITS primers $\left(\mathrm{T}_{\mathrm{a}}\right.$ at $\left.60^{\circ} \mathrm{C}\right)$. The difference in $\mathrm{Ct}$ values when performing the qPCR on the same two replicate dilution series of template copies $\left(10^{5}\right.$ to $10^{1}$ $\mathrm{pDNA}_{\text {ITS }}$ and $\mathrm{pDNA}_{\mathrm{TUB}}$ copies) was used to correct for possible differences in amplification efficiency ( $\left.\Delta \mathrm{Ct}_{\text {plasmid }}\right)$. The $\Delta \mathrm{Ct}$ values were calculated at the average tested template level, where the standard deviation of the estimated $\mathrm{Ct}$ values was the smallest. The ITS copy-number per genome was calculated using the following equation (19): number of ITS copies $=2^{\text {(ACtgen }-\Delta \text { Ctplasmid })}$. C. buxicola conidia are two-celled, with one nucleus each $(16,28)$. The number of ITS targets per conidium can consequently be estimated as $2^{(\Delta \text { Ctgen }-\Delta \text { Ctplasmid }+1)}$.

Detection and quantification of $\boldsymbol{C}$. buxicola conidia in water samples. To increase the sensitivity and sample size of the $C$. buxicola conidium detection assay in water, a centrifugation-based protocol was developed to concentrate the conidia in a smaller sample volume. Water samples of 100,10 , or $1 \mathrm{ml}$ containing a known concentration of conidia were centrifuged for $5 \mathrm{~min}$ at 6,800 rcf using an Avanti J26XP Hi-Speed Centrifuge (Beckman-Coulter). Then, $90 \%$ of the volume was drained and the pellet resuspended in the remaining $10 \%$ sample volume by vortexing. Preliminary assays determined a recovery rate of $95.5 \pm 10.6 \%(n=4)$ of the initial amount of conidia at each similar concentration step.

To assess the LOD of conidia in water samples using the optimal ITS construct, three independent dilution series of 10-ml samples were established in 15-ml conical Falcon tubes (Corning), using rainwater collected at the research site (Merelbeke, Belgium) and containing total amounts of $10,000,1,000,100,10$, or 0 conidia. Water samples taken in nurseries (for instance, in water puddles or water drains) are often turbid, containing soil or debris that could interfere with the efficiency of sample preparation, DNA extraction, and qPCR amplification. To simulate those conditions, three additional independent dilution series were created as described above but with the addition of $100 \mathrm{mg}$ of field soil (Merelbeke, Belgium). The different water samples are hereafter referred to as "clear" (no soil added) or "turbid" (100 mg of soil added). These samples were first concentrated to $1-\mathrm{ml}$ volumes as described above, transferred to $1.5-\mathrm{ml}$ microcentrifuge tubes, and concentrated a second time, resulting in a final volume of $100 \mu \mathrm{l}$. DNA was extracted from this volume using the most optimal DNA extraction kit (see Results section). Two 5- $\mu$ l DNA samples from a total elution volume of $100 \mu \mathrm{l}$ were submitted to qPCR analysis using the optimal ITS construct and the optimized thermocycling conditions.

The detection protocol for water samples was tested using water samples collected at a stand of C. buxicola-infected B. sempervirens 'Suffruticosa' plants at a mock nursery in Destelbergen (Belgium). Four open plastic containers $(20$ by 30 by $5 \mathrm{~cm}$ ) were placed at $50 \mathrm{~cm}$ of distance from rows of symptomatic plants prior to a predicted period of rain. The water from each container was collected the next day. Subsamples $(100 \mathrm{ml})$ were processed using the protocol described above, except that the 100-ml subsamples were concentrated to $1 \mathrm{ml}$ in a single centrifugation step, using 175-ml conical Falcon tubes (Nunc).

Detection and quantification of $C$. buxicola conidia in air samples. Air sampling was conducted using a Burkard 7-day re- 
cording volumetric spore trap (Burkard Manufacturing) with the standard orifice. Melinex tape was thinly layered with a 5:1 (vol/vol) mixture of white vaselin (VWR International) and paraffin oil (VWR International) as done for standard sampling, cut in pieces representing $12 \mathrm{~h}$ of sampling, spiked with $10 \mu \mathrm{l}$ of $C$. buxicola conidium suspensions, and allowed to dry. Three independent dilution series were established, resulting in 1,000, 100, 10, or 0 conidia per tape piece. The fragments were transferred into 2-ml microcentrifuge tubes with the coated surface facing the center of the tube, and approximately $200 \mathrm{mg}$ of $0.5-\mathrm{mm}$ Zirconia/Silica beads (BioSpec Products) were added. DNA was extracted using the most optimal DNA extraction kit following the manufacturer's instructions, except for the addition of three bead-beating cycles at 10 -min intervals during the lysis phase. Each cycle consisted of $2 \times$ $30 \mathrm{~s}$ bead beating at $30 \mathrm{~Hz}$ using an MM301 bead beater (RETSCH Technology). Two 5- $\mu$ l DNA subsamples of a total elution volume of $50 \mu \mathrm{l}$ were submitted to qPCR analysis using the optimal ITS construct and optimized thermocycling conditions.

The detection protocol for air samples was tested using samples collected at the same stand with $C$. buxicola-infected boxwood plants (see protocol for water samples above). The Burkard spore trap was placed in the center of the field and allowed to sample continuously for 7 days. Samples were processed as described above.

Detection and quantification of $C$. buxicola in infected plant samples. Twigs from healthy 2-year-old $B$. sempervirens plants were collected and submerged for $10 \mathrm{~s}$ in a $C$. buxicola (isolate CB002) suspension of $10^{4}$ conidia/ml. Twigs submerged in sterile water served as healthy controls. All plant material was incubated at $20^{\circ} \mathrm{C}$ in covered plastic boxes of 25 by $40 \mathrm{~cm}$ containing moist Wypall wipers (Kimberly-Clark). Seven days post inoculation, $20 \mathrm{~g}$ of $100 \%$ necrotic leaves and $20 \mathrm{~g}$ of noninoculated leaves were collected, hereafter referred to as $100 \%$ infected and $100 \%$ noninfected leaf material, respectively. Each leaf sample was separately blended in $200 \mathrm{ml}$ of 0.1 Tris- $\mathrm{HCl}$ buffer $(\mathrm{pH} \mathrm{8)}$ using a GM200 mixer (RETSCH Technology) at 10,000 rpm for $5 \mathrm{~min}$. To determine the detection limit of $C$. buxicola in infected plant materials, two independent dilution series were established. In each series, 2 $\mathrm{ml}$ of the blended $100 \%$ infected material was serially diluted with
$18 \mathrm{ml}$ of the blended $100 \%$ noninfected material, creating samples with $100 \%\left(10^{6} \mathrm{ppm}\right)$ to $0.0001 \%\left(10^{0} \mathrm{ppm}\right)$ infected leaf material. Each sample $(1 \mathrm{ml})$ was centrifuged for $2 \mathrm{~min}$ at 20,000 rcf and DNA was extracted from the pellet using the most optimal DNA extraction kit (see Results section), following the manufacturer's instructions. The total DNA concentration (plant + pathogen) was quantified using a Nanodrop spectrophotometer. The maximum amount of template DNA that could be used in the qPCR without interference from co-extracted PCR-inhibiting compounds was determined by adding 1,10 , and $50 \mathrm{ng}$ of total gDNA of the $10^{4}$ and $10^{2}$-ppm samples as template in the ITS TaqMan qPCR assay in duplicate and comparing the theoretical with the observed $\mathrm{Ct}$ values. To determine the detection threshold of $C$. buxicola in infected plant material, the amount of $C$. buxicola DNA was quantified using two replicate qPCR reactions and the maximum allowed amount of extracted DNA sample.

The detection protocol for plant samples was validated using relatively large samples $(20 \mathrm{~g})$ collected from asymptomatic plants or symptomatic, naturally infected plants of the following Buxus spp. and cultivars: $B$. sempervirens, $B$. sempervirens Suffruticosa, B. microphylla 'Faulkner', and B. microphylla 'Trompenburg'. Plant species and cultivars were selected based on $C$. buxicola lesion size and disease incidence. The asymptomatic and symptomatic plants originated from different fields. From each species or cultivar, three leaf + twig samples $(\mathrm{A}-\mathrm{B}-\mathrm{C})$ were taken: plant material from asymptomatic plants (A), asymptomatic portions of diseased plants (B), and symptomatic plant material from diseased plants (C). Each sample was processed as described above.

\section{Results}

Primer design and evaluation. The QPP kit was selected for DNA extraction of fungal mycelium for the validation of the qPCR assays, because it yielded a large amount of high-quality DNA and had favorable labor and material costs (data not shown). When targeting the ITS regions, a TaqMan MGB Probe was essential to obtain sufficient specificity between different Cylindrocladium spp. During the preliminary test, the ITS primer pair/TaqMan construct F494 (5'-CGTCATTTCAACCCTCAA-3')/MGB539 (5'-6FAMATCGGCAGAGCGTCCT-MGB-3')/R621 (5'-GGTGTATTACTA

Table 2. Threshold cycle $(\mathrm{Ct})$ values (mean \pm standard deviation, $n=3$ ) of quantitative polymerase chain reaction amplifications testing the specificity of the ribosomal DNA internal transcribed spacer region (ITS) TaqMan construct F494/MGB539/R621 (annealing temperatures 60, 62, and 64 ${ }^{\circ} \mathrm{C}$ ) and the $\beta$-tubulin 2 gene (TUB) SYBR Green construct F250/R462 (annealing temperature $60^{\circ} \mathrm{C}$ ) for Cylindrocladium buxicola target DNA ${ }^{\mathrm{x}}$

\begin{tabular}{|c|c|c|c|c|c|}
\hline \multirow[b]{3}{*}{ Organism } & \multirow[b]{3}{*}{ Isolate code } & \multicolumn{4}{|c|}{ Ct values $(100 \text { pg of gDNA) })^{y}$} \\
\hline & & \multicolumn{2}{|c|}{ ITS construct (TaqMan) } & \multicolumn{2}{|c|}{ TUB construct (SYBR Green) } \\
\hline & & $60^{\circ} \mathrm{C}$ & $62^{\circ} \mathrm{C}$ & $64^{\circ} \mathrm{C}$ & $60^{\circ} \mathrm{C}$ \\
\hline Cylindrocladium buxicola & $\mathrm{CB} 002$ & $22.73 \pm 0.08$ & $22.87 \pm 0.06$ & $27.87 \pm 0.19$ & $24.61 \pm 0.09$ \\
\hline C. buxicola & CB045 & $22.79 \pm 0.10$ & $22.92 \pm 0.04$ & $27.86 \pm 0.22$ & $24.68 \pm 0.03$ \\
\hline C. buxicola & RHS PT25 & $22.77 \pm 0.06$ & $23.15 \pm 0.15$ & $29.13 \pm 0.57$ & $24.92 \pm 0.09$ \\
\hline C. colhounii & Ccol001 & $>40$ & $>40$ & $>40$ & $>40$ \\
\hline C. parasiticum ${ }^{\mathrm{z}}$ & Cpara002 & $28.28 \pm 0.04$ & $29.69 \pm 0.22$ & NA & $>40$ \\
\hline C. pauciramosum & Cpauc001 & $>40$ & $>40$ & $>40$ & $>40$ \\
\hline C. scoparium & Cscop001 & $>40$ & $>40$ & $>40$ & $>40$ \\
\hline Aspergillus westerdijkiae & ASP & $>40$ & $>40$ & $>40$ & $>40$ \\
\hline Botrytis cinerea & PCF1080 & $>40$ & $>40$ & $>40$ & $>40$ \\
\hline Colletotrichum acutatum & PCF721 & $>40$ & $>40$ & $>40$ & $>40$ \\
\hline Cladosporium halotolerans & CLA & $>40$ & $>40$ & $>40$ & $>40$ \\
\hline Fusarium oxysporum & PSKW2 & $>40$ & $>40$ & $>40$ & $>40$ \\
\hline Penicillium chrysogenum & KVP201 & $>40$ & $>40$ & $>40$ & $>40$ \\
\hline Trichoderma sp. & TRI & $>40$ & $>40$ & $>40$ & $>40$ \\
\hline Verticillium nonalfalfae & Va1 & $>40$ & $>40$ & $>40$ & $>40$ \\
\hline V. buxi & VB005 & $>40$ & $>40$ & $>40$ & $>40$ \\
\hline V. dahliae & Ve005 & $>40$ & $>40$ & $>40$ & $>40$ \\
\hline $\mathrm{a}$ & $\ldots$ & -3.41 & -3.65 & -5.29 & -3.78 \\
\hline $\mathrm{b}$ & $\ldots$ & 38.54 & 39.88 & 53.6 & 36.35 \\
\hline$R^{2}$ & $\ldots$ & 0.998 & 0.999 & 0.998 & 0.997 \\
\hline
\end{tabular}

${ }^{\mathrm{x}}$ Standard curves $[\mathrm{Ct}$ value $=\mathrm{a} \times \log ($ target copies $)+\mathrm{b}]$ were constructed by including reactions containing 10 -fold dilution series of plasmid DNA of reference strain $\mathrm{CB} 002$ per reaction $\left(10^{6}\right.$ to $10^{2}$ copies /reaction).

${ }^{\text {y }} \mathrm{Ct}>40$ was considered as the cut off value; $\mathrm{gDNA}=$ genomic DNA; $\mathrm{NA}=$ data not available.

z Tested independently with $100 \mathrm{pg}$ of gDNA of CB002 as internal reference. Not conducted at annealing temperature of $64^{\circ} \mathrm{C}$. 
CGCAGAG- $\left.3^{\prime}\right)$ and the TUB primer pair F250 (5'-GTGCGTAAG TGCTCAATC-3')/R462 (5'-TACATACCTCGTTGAAGTAGA-3') eventually proved superior in terms of both sensitivity and specificity (data not shown) and, therefore, were selected for further evaluation.

Validation of specificity, sensitivity, and intra- and interassay variance. Results of the specificity testing are listed in Table 2. Using the ITS TaqMan construct F494/MGB539/R621 at $\mathrm{T}_{\mathrm{a}} \mathrm{s}$ of 60,62 , and $64^{\circ} \mathrm{C}, 100 \mathrm{pg}$ of $C$. buxicola gDNA was detected at mean $\mathrm{Ct}$ values \pm standard deviation (stdev) of $22.8 \pm 0.0,23.0 \pm$ 0.2 , and $28.3 \pm 0.7$, respectively. The amplification efficiency $\mathrm{E}$, calculated using the slope of the regression curve of an internal 10fold dilution series of pDNA, was clearly inferior $(\mathrm{E}=0.55)$ at $64^{\circ} \mathrm{C}$ compared with the amplification efficiencies at annealing temperatures $60^{\circ} \mathrm{C}(\mathrm{E}=0.95)$ and $62^{\circ} \mathrm{C}(\mathrm{E}=0.88)$. No amplification $(\mathrm{Ct}>40)$ was observed in NTC reactions or in reactions containing gDNA of non-target organisms, with the exception of $C$. parasiticum, which was detected at $\mathrm{Ct}$ values of $28.2 \pm 0.0$ $\left(\mathrm{T}_{\mathrm{a}} 60^{\circ} \mathrm{C}\right)$ and $29.7 \pm 0.2\left(\mathrm{~T}_{\mathrm{a}} 62^{\circ} \mathrm{C}\right)$. The ITS TaqMan construct, however, proved to be $47\left(\mathrm{~T}_{\mathrm{a}} 60^{\circ} \mathrm{C}\right)$ and $113\left(\mathrm{~T}_{\mathrm{a}} 62^{\circ} \mathrm{C}\right)$ times less sensitive for $C$. parasiticum gDNA than for $C$. buxicola gDNA (isolate CB002), respectively. The $\mathrm{T}_{\mathrm{a}} 62^{\circ} \mathrm{C}$ resulted in the highest specificity in combination with good amplification efficiency and, therefore, was integrated in the thermocycling profile when using the ITS TaqMan construct in further research. Using the TUB SYBR Green construct F250/R462, the $100 \mathrm{pg}$ of gDNA of the different $C$. buxicola isolates was detected at an average $\mathrm{Ct}$ value \pm stdev of 24.7 $\pm 0.2(\mathrm{E}=0.84)$. Although the TUB SYBR Green construct was about four times $\left(\Delta \mathrm{Ct}\right.$ approximately $\left.2, \mathrm{~T}_{\mathrm{a}} 60^{\circ} \mathrm{C}\right)$ less sensitive than the ITS TaqMan construct, the TUB SYBR Green construct proved to be more specific, with $\mathrm{Ct}$ values $>40$ for all NTC reactions or reactions containing gDNA of the listed non-target organisms.

Within each of the three qPCR runs on the dilution series of gDNA and pDNA, the six replicates were highly similar at each template level (coefficients of variation $[\mathrm{CVs}]<3 \%$ ), indicating low intra-assay variance. The $\mathrm{CVs}$ between the average $\mathrm{Ct}$ values of the three qPCR runs were smaller than $5 \%$ at each template level, demonstrating low inter-assay variance. Highly linear correlations $\left(R^{2}>0.99\right)$ were found between the log of the DNA concentration and the $\mathrm{Ct}$ values in each of the three replicate qPCR runs. Standard curves based on the average $\mathrm{Ct}$ values of the three independent qPCR runs are shown in Figure 1A and B for gDNA and pDNA, respectively. Because the slope of the standard curves was not significantly different for pDNA template versus gDNA template ( $P=0.20$, two-sided student's $t$ test), pDNA can be used reliably for the assembly of standard curves and, thus, the quantification of $C$. buxicola in unknown DNA samples. Based on the two regression equations, an estimated 818 ITS target copies are present per picogram of $C$. buxicola gDNA.

qPCR assays with small amounts of gDNA and $\mathrm{pDNA}_{\text {ITS }}$ revealed that the ITS TaqMan construct reliably detected $10 \mathrm{fg}$ of gDNA (mean Ct value \pm stdev of $37.4 \pm 1.0$ ) and 20 targets of $\mathrm{pDNA}_{\text {ITS }}$ (mean $\mathrm{Ct}$ value \pm stdev of $37.0 \pm 1.0$ ). Although four of six qPCR reactions containing 10 targets of pDNA $_{\text {ITS }}$ produced amplicons (mean Ct value \pm stdev of $38.8 \pm 0.4$ ), this was not considered to be a reliable detection threshold, which we define as six of six qPCR reactions with positive amplification.

Estimation of ITS copy number. Linear regression curves from SYBR Green qPCR reactions using the ITS SYBR Green construct F494/R621 and the TUB SYBR Green construct, and 10-fold dilutions of gDNA or pDNA of reference strain C. buxicola CB002 as templates, are also shown in Figure $1 \mathrm{~A}$ and $\mathrm{B}$. The simultaneous amplification of the same number of $\mathrm{pDNA}_{\mathrm{ITS}}$ and $\mathrm{pDNA}_{\mathrm{TUB}}$ targets demonstrated highly similar efficiencies of both primer sets, with the TUB SYBR Green construct being slightly more efficient $(\Delta \mathrm{Ct}$ plasmid $=0.25$ at $\log [$ target copy number $]=4)$. Melting curve analysis on the pDNA samples used in this SYBR Green qPCR assay revealed mean \pm stdev melting temperatures of $84.3 \pm$ $0.2^{\circ} \mathrm{C}(n=8)$ for the ITS fragment and $83.7 \pm 0.1^{\circ} \mathrm{C}(n=8)$ for the TUB fragment. Using gDNA as template, the ITS SYBR Green construct produced lower $\mathrm{Ct}$ values than the TUB SYBR Green construct $(\Delta \mathrm{Ct}$ gen $=6.0$ at $\log (\mathrm{fg}$ gDNA $)=4)$, making the ITS SYBR Green construct about 64 times more sensitive. Based on the differences in $\mathrm{Ct}$ values when amplifying gDNA and pDNA, each $C$. buxicola genome contains an estimated 75.6 ITS tandem repeats [number of ITS copies/genome $=2^{(\Delta \text { Ctgen }-\Delta \text { Ctplasmid })}$ ]. Theoretically, each conidium should therefore contain an estimated 151 ITS targets [number of ITS copies/conidium $=2^{(\Delta \text { Ctgen }-\Delta \text { Ctplasmid }+1)}$ ].

Detection and quantification of conidia in water samples. The PS kit was selected for DNA extraction of $C$. buxicola conidia in clear as well as turbid water samples, because this kit resulted in the highest recovery during preliminary DNA extraction and qPCR tests (data not shown). To simplify handling, lysis buffer and beads were added directly to the $2-\mathrm{ml}$ microcentrifuge tubes. The remaining part of the protocol was performed following the manufacturer's instructions.

Strong linear correlations $\left(R^{2}>0.99\right)$ were found between the $\mathrm{Ct}$ values and the log amount of initial conidia for both the clear and
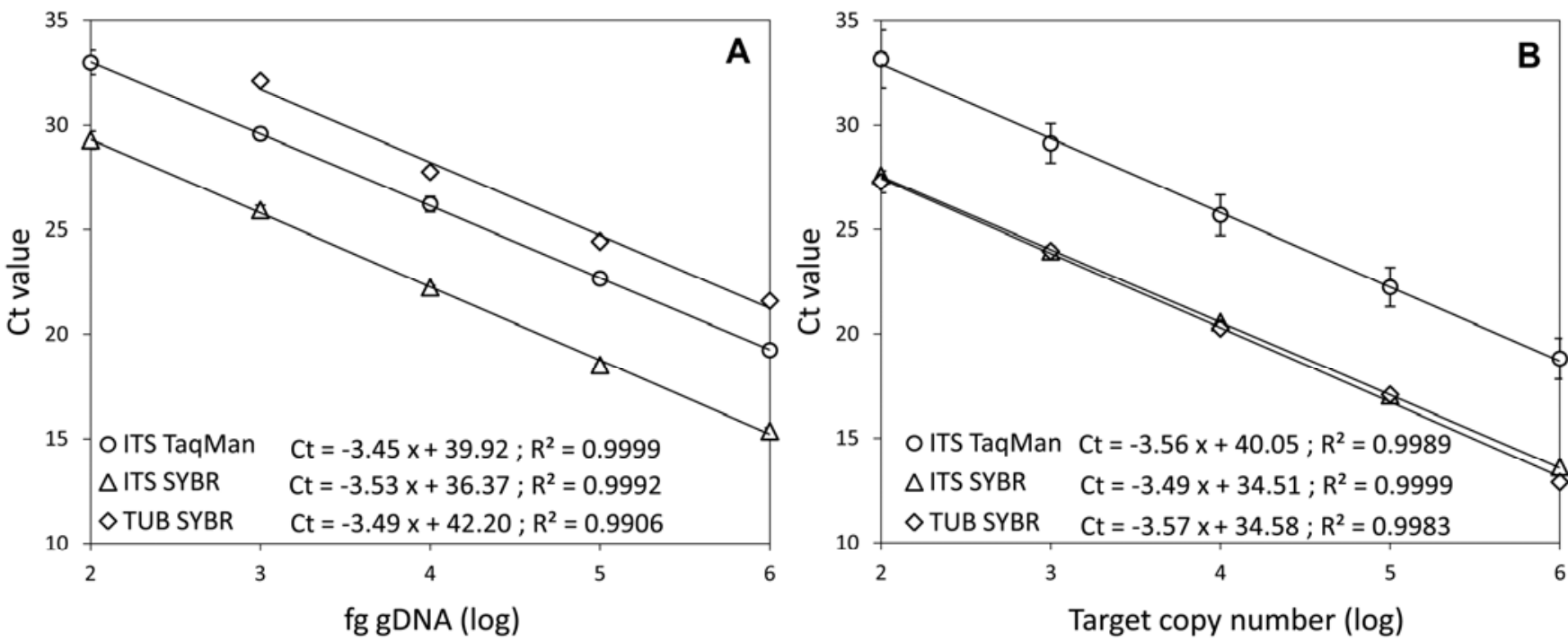

Fig. 1. Linear regression curves from TaqMan quantitative polymerase chain reaction (qPCR) reactions (annealing temperature $\left[T_{a}\right]=62^{\circ} \mathrm{C}$ ) using the construct F494/MGB539/R621 and SYBR Green qPCR reactions $\left(T_{a}=60^{\circ} \mathrm{C}\right)$ using the constructs ribosomal DNA internal transcribed spacer 1 (ITS) F494/R621 and $\beta$-tubulin 2 gene (TUB) F250/R462. Assays were conducted using either A, genomic DNA or B, cloned target DNA from reference Cylindrocladium buxicola strain CB002. Error bars represent standard deviations from three $\mathrm{QPCR}$ runs with six replicates each (ITS TaqMan) or two replicate runs (ITS SYBR and TUB SYBR). Ct $=$ threshold cycle. 
turbid water samples (Fig. 2A). In clear water samples, 1 conid$\mathrm{ium} / \mathrm{ml}$ of water $(=0.5$ conidium-equivalents or 1 genome-equivalent per qPCR reaction) was detected at a Ct value \pm stdev of 33.4 \pm 0.1 , representing 59.9 ITS targets based on the internal pDNA standard curve $[\mathrm{Ct}=-3.5 \times \log$ (target copy number $)+40.4 ; R^{2}>$ 0.99]. Although the sensitivity in turbid samples was about four times lower than detection in clear water samples $[\Delta \mathrm{Ct}=2.05$ at $\log$ (number of conidia $)=2.5$ ], a sample of 1 conidium $/ \mathrm{ml}$ of water could still be detected at a $\mathrm{Ct}$ value \pm stdev of $35.7 \pm 0.3$, representing 13.8 ITS targets.

Substantial amounts of $C$. buxicola DNA were detected in all the water samples (Table 3$)$, translating to an average $\pm \operatorname{stdev}(n=4)$ of 7,155.5 $\pm 4,654.5$ conidium equivalents per $100 \mathrm{ml}$ of water.

Detection and quantification of conidia in air samples. Yielding the highest recovery of template DNA during preliminary tests, the DP kit was selected for DNA extraction of $C$. buxicola conidia in air samples (data not shown). A strong linear correlation $\left(R^{2}>\right.$ 0.99) was found between the $\mathrm{Ct}$ values and the log amount of initial conidia (Fig. 2B). Ten conidia per Melinex tape fragment (one conidium-equivalent or two genome-equivalents per qPCR reac-
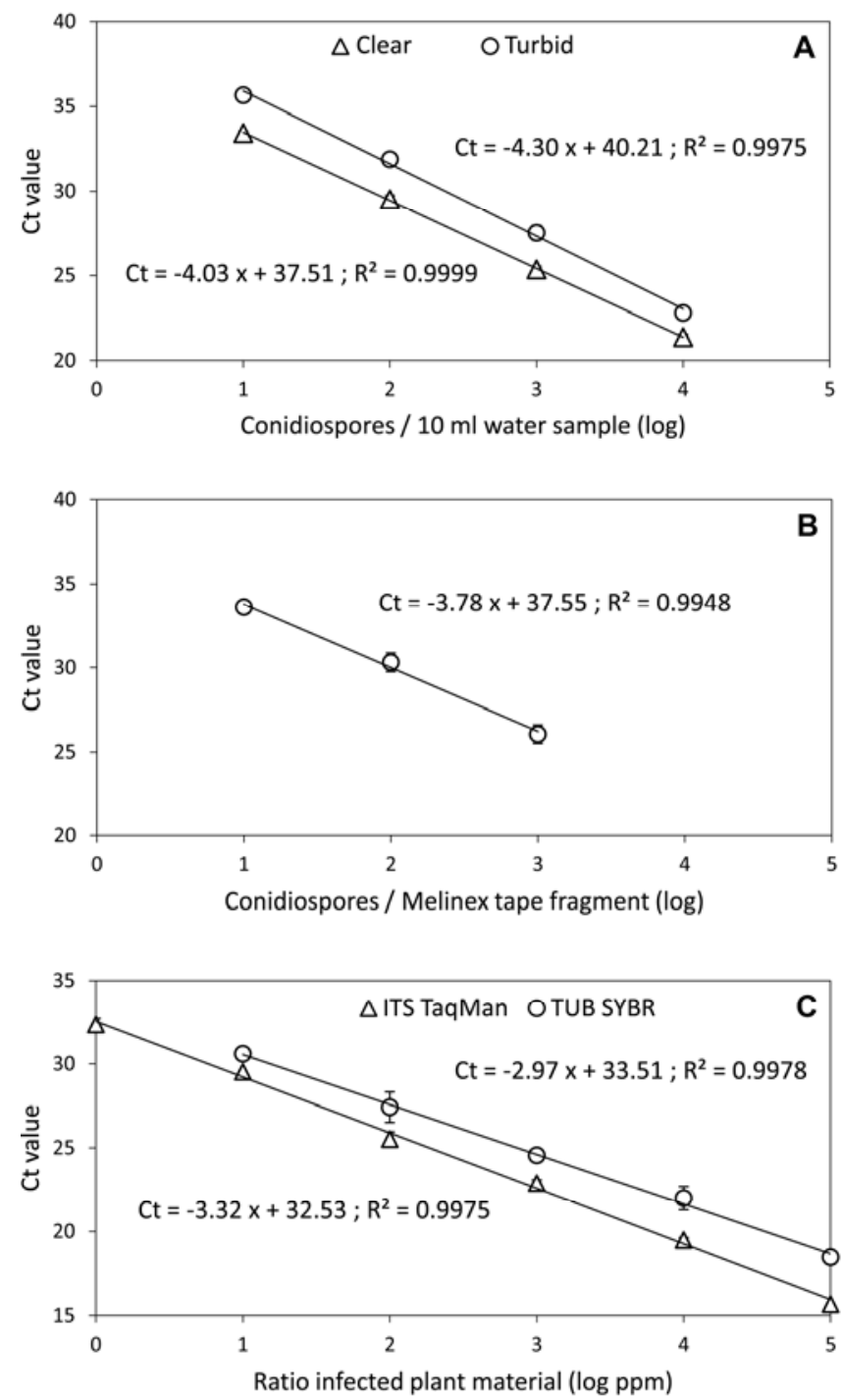

Fig. 2. Quantitative detection of Cylindrocladium buxicola A, in clear (no soil added) and turbid (100 mg of soil added) water samples; $\mathbf{B}$, on Melinex tape fragments used for air samples; and $\mathbf{C}$, in plant samples, following optimized sample processing and DNA extraction protocols and using either the ribosomal DNA internal transcribed spacer 1 (ITS) TaqMan construct F494/MGB539/R621 (annealing temperature $\left.\left[T_{a}\right]=62^{\circ} \mathrm{C}\right)(\mathrm{A}, \mathrm{B}$, and $\mathrm{C})$ or the $\beta$-tubulin 2 gene (TUB) SYBR Green construct $F 250 / R 462\left(T_{a}=60^{\circ} \mathrm{C}\right)(C)$ in quantitative polymerase chain reaction assays. Error bars represent standard deviations from two $(C)$ or three $(A$ and $B$ ) independent DNA extractions. $\mathrm{Ct}=$ threshold cycle. tion) were detected at a $\mathrm{Ct}$ value \pm stdev of $33.6 \pm 0.3$, representing 90.6 ITS targets (45.3 ITS targets per genome-equivalent) based on the internal standard curve $[\mathrm{Ct}=-3.5 \times \log$ (target copy number) + 39.7, $\left.R^{2}>0.99\right]$.

C. buxicola could be detected above the reliable LOD level in only 4 of 14 tape fragments representing the air samples (Table 3 ). Those four air samples contained only small amounts of $C$. buxicola DNA, translating to an average $\pm \operatorname{stdev}(n=4)$ of $6.2 \pm 3.6$ conidium equivalents per $12 \mathrm{~h}$ of air sampling (Table 3 ).

Detection and quantification of mycelium in plant samples. Following preliminary tests, the ISP kit yielded the highest amounts of $C$. buxicola DNA per total DNA extracted (data not shown) and, therefore, was selected for DNA extraction from plant samples. No inhibition or nonspecific amplification reactions were observed when 1 to $50 \mathrm{ng}$ of total DNA (host + pathogen gDNA) from infected leaf material was used per PCR reaction. Therefore, the addition of $50 \mathrm{ng}$ of total gDNA was selected for further use.

Strong linear relationships $\left(R^{2}>0.99\right)$ were observed between the $\mathrm{Ct}$ values and the log (ppm infected plant material) when the gDNA extracts of the samples with different ratios of infected material were qPCR amplified using both the ITS TaqMan and the TUB SYBR Green construct (Fig. 2C). Using the ITS TaqMan construct, the lowest tested proportion of infected leaf material at 1 ppm was reliably detected at a $\mathrm{Ct}$ value \pm stdev of $32.4 \pm 0.4$. When using the TUB SYBR Green construct, infected leaf material at $10 \mathrm{ppm}$ was reliably detected at a $\mathrm{Ct}$ value \pm stdev of $30.6 \pm 0.1$. Detection of $100 \%$ infected leaf material $\left(10^{6} \mathrm{ppm}\right)$ was possible with both constructs but at about $1 \mathrm{Ct}$ value higher than expected based on the regression curves of the remaining data points $(\mathrm{Ct}$ 13.7 versus 12.6 for the ITS TaqMan construct and $\mathrm{Ct} 16.5$ versus 15.7 for the TUB SYBR Green construct). Because this is likely the effect of co-extracted PCR inhibitors present in large amounts in $100 \%$ infected plant material, these points were not included in the regression.

All of the samples originating from asymptomatic plants (A samples) tested negative $(\mathrm{Ct}>40)$ for the presence of $C$. buxicola (Table 4). All of the samples including symptomatic plant material (C samples) tested positive for $C$. buxicola, with gDNA amounts ranging from $125 \mathrm{fg}$ (B. microphylla Trompenburg, with very low disease severity) to $194,824 \mathrm{fg}$ (B. sempervirens Suffruticosa, with high disease severity) per $50 \mathrm{ng}$ of total gDNA (C. buxicola + Buxus host). Presence of $C$. buxicola DNA was detected in the asymptomatic plant samples obtained from diseased plants (B samples) from the cultivars B. sempervirens Suffruticosa (443 $\mathrm{fg})$, B. sempervirens (288 fg), and B. microphylla Trompenburg (79 fg).

\section{Discussion}

Reliable detection and quantification of $C$. buxicola in boxwood tissue and in environmental samples requires a quantitative technique that is both specific and sensitive. This research focused on the development and validation of qPCR assays and their applica-

Table 3. Quantification of Cylindrocladium buxicola (number of conidium equivalents) in water and air samples taken from a field with symptomatic Buxus sempervirens 'Suffruticosa' plants $^{\mathrm{y}}$

\begin{tabular}{|c|c|c|c|}
\hline \multicolumn{2}{|c|}{ Water samples $(100 \mathrm{ml})$} & \multicolumn{2}{|c|}{ Air samples $(7,200 \text { liters })^{\mathrm{z}}$} \\
\hline Container & $\begin{array}{l}\text { Number of } \\
\text { equivalents }\end{array}$ & $\begin{array}{c}\text { Sampling } \\
\text { period }(12 \mathrm{~h})\end{array}$ & $\begin{array}{l}\text { Number of } \\
\text { equivalents }\end{array}$ \\
\hline A & $13,231.7$ & 1 & 4.9 \\
\hline B & $6,119.3$ & 2 & 4.5 \\
\hline $\mathrm{C}$ & $7,311.7$ & 5 & 3.8 \\
\hline D & $1,961.6$ & 14 & 11.5 \\
\hline
\end{tabular}

${ }^{\mathrm{y}}$ Water samples (rain and rain splash) were taken in four containers (A to D) 1 day after placement. Continuous air sampling at 10 liters/min was conducted for 7 days, represented by 14 consecutive sampling periods of $12 \mathrm{~h}$ (samples 1 to 14 ).

${ }^{z}$ Only air samples with a detection higher than the reliable limit of detection ( 2.2 conidium equivalents) were included. 
bility in detecting C. buxicola in Buxus plant material and C. buxicola conidia in water and air samples.

Candidate primers and TaqMan probes were designed based on the alignments of GenBank sequence data. The TUB sequences displayed a considerable number of interspecific polymorphisms, allowing the design of several potential C. buxicola-specific primers. When using the Basic Local Alignment Search Tool (BLAST) with the TUB sequence of our reference $C$. buxicola isolate CB002 as input sequence, only $91 \%$ (score 695) and $84 \%$ (score 499) similarity was found with the two most closely related Cylindrocladium spp., C. multiphialidicum (GenBank accession code AY725628) and C. naviculatum (GenBank accession code GQ267211), respectively (38). Because the majority of the candidate primer pairs were specific with the species tested, primers F250/R462 were selected based on their superior sensitivity. In contrast with the TUB sequences, little interspecific variability was found between the ITS sequences of the Cylindrocladium/ Calonectria spp., strongly limiting the options for developing specific primers using this target. When performing a BLAST using the ITS sequence of $\mathrm{CB} 002$ as input, 99 and 98\% similarities (scores > 900) were found with almost all GenBank submissions of Cylindrocladium/Calonectria ITS sequences. Only one C. buxicola-unique feature for specific primer/probe design was found in the ITS sequence alignment: base pair 351 of GenBank accession HM749646. Creating a TaqMan MGB probe covering this unique single-nucleotide polymorphism was considered to be the best chance to create sufficient specificity (35). Eventually, the nonspecific ITS primers F494 and R621 were combined with the TaqMan MGB probe MGB539, because this combination yielded the highest specificity and sensitivity.

A SYBR Green qPCR assay using the ITS and TUB primers simultaneously on the respective plasmid DNA dilution series and the same gDNA dilution series allowed an estimation of the relative number of ITS and TUB target copies. Because TUB is a single-copy gene, this allowed calculation of the number of ITS targets per $C$. buxicola genome. This number was 76 , which is similar to higher in comparison with other studies in which the fungal ITS copy number was determined. Alaei et al. (2) estimated 80 rDNAITS targets per haploid genome of the rust Puccinia horiana whereas, in Colletotrichum acutatum, the ITS copy number was estimated at 19.7 (19). Because of the estimated 76 ITS tandem repeats, an ITS-based qPCR assay has the potential to be far more sensitive than any qPCR assay using a single-copy gene such as TUB.
The selected TUB primers were highly specific, because no amplification $(\mathrm{Ct}>40)$ was observed when adding a large amount of template (100 pg of gDNA) of the non-target organisms. It is possible that the phylogenetically most closely related Cylindrocladium sp., Cylindrocladium multiphialidicum (38) (GenBank accession code AY725628), might give some degree of amplification (only one mismatch to F250 primer: 5'-GTGCGTAAGT(A)CTCAATC$\left.3^{\prime}\right)$. It is highly unlikely, however, to find C. multhiphialidicum in the same ecological niche as $C$. buxicola. To our knowledge, this species has only been described in soils surrounding the root systems of Musa spp. in Cameroon (17). In addition, melt curve analysis should help differentiate these two species.

When testing the specificity of the ITS TaqMan construct F494/MGB539/R621 with the listed non-target organisms, $100 \mathrm{pg}$ of gDNA of $C$. parasiticum isolate Cpara002 was detected, but at a much higher $\mathrm{Ct}$ value $\left(\Delta \mathrm{Ct}\right.$ approximately 6.8 at $\left.\mathrm{T}_{\mathrm{a}}=62^{\circ} \mathrm{C}\right) . C$. parasiticum has only one mismatched nucleotide with the TaqMan MGB probe, resulting in inefficient amplification but apparently not full specificity. This is also expected in other Cylindrocladium spp. that only have the identical one-nucleotide mismatch, such as $C$. naviculatum and $C$. canadense. However, due to the reduced PCR efficiency, these species would have to be present at high levels (only expected in infected plant samples) to give a false-positive result, and this is not possible because they are not known to infect Buxus spp. C. colhounii, C. scoparium, and C. pauciramosum all have an identical two-nucleotide mismatch (base pairs 350 and 351 of GenBank accession HM749646), resulting in full specificity.

The LOD is commonly defined as the concentration that can still be detected with $95 \%$ probability (11). Theoretically, the lowest LOD is three target copies per PCR, assuming a Poisson distribution, a 95\% chance of including at least one copy in the PCR reaction, and single-copy detection (11). Using the average regression equations defined on the ITS TaqMan amplification results of dilution series of gDNA and $\mathrm{pDNA}_{\text {ITS }}, 818$ ITS targets were estimated for each pictogram of gDNA of $C$. buxicola, and 3 ITS targets consequently correspond to $3.7 \mathrm{fg}$ of gDNA. Based on these concentrations of gDNA and $\mathrm{pDNA}_{\mathrm{ITS}}$ and the average regression curves (Fig. 1), these lowest LODs correspond to $\mathrm{Ct}$ values of 38.0 and 38.4, respectively. In the qPCR reaction series, reliable LODs of 20 targets of pDNA ${ }_{\text {ITS }}$ (mean Ct value of 37.0) and $10 \mathrm{fg}$ of gDNA (mean $\mathrm{Ct}$ value of 37.4) were observed, which are in the range of the theoretical expectations.

Based on the estimated multi-copy number and the similarity in efficiency of the developed ITS and TUB primers, LODs for

Table 4. Detection of Cylindrocladium buxicola in plant samples of four different Buxus cultivars using the ribosomal DNA internal transcribed spacer region TaqMan construct (annealing temperature of $\left.62^{\circ} \mathrm{C}\right)^{\mathrm{x}}$

\begin{tabular}{|c|c|c|c|c|}
\hline Cultivar, sample type & $\begin{array}{l}\text { Severity of symptoms } \\
\text { on sampled plants }\end{array}$ & $\begin{array}{l}\text { Severity of symptoms } \\
\text { on plant samples }\end{array}$ & $\begin{array}{c}\text { Ct-value } \pm \text { stdev } \\
\quad(n=2)^{\mathrm{y}}\end{array}$ & $\begin{array}{c}\operatorname{gDNA}(\mathbf{f g}) \pm \text { stdev } \\
\quad(n=2)^{\mathrm{z}}\end{array}$ \\
\hline \multicolumn{5}{|c|}{ Buxus microphylla 'Trompenburg' } \\
\hline A & No symptoms & No symptoms & $>40$ & $<3$ \\
\hline B & Very low & No symptoms & $35.1 \pm 0.7$ & $79 \pm 30$ \\
\hline $\mathrm{C}$ & Very low & Very low & $34.3 \pm 0.3$ & $125 \pm 20$ \\
\hline \multicolumn{5}{|c|}{ B. microphylla 'Faulkner' } \\
\hline A & No symptoms & No symptoms & $>40$ & $<3$ \\
\hline B & Low & No symptoms & $>40$ & $<3$ \\
\hline $\mathrm{C}$ & Low & Low & $30.0 \pm 0.1$ & $1,532 \pm 78$ \\
\hline \multicolumn{5}{|l|}{ B. sempervirens } \\
\hline A & No symptoms & No symptoms & $>40$ & $<3$ \\
\hline B & Medium & No symptoms & $33.2 \pm 1.6$ & $288 \pm 235$ \\
\hline $\mathrm{C}$ & Medium & Medium & $26.0 \pm 0.1$ & $16,557 \pm 370$ \\
\hline \multicolumn{5}{|c|}{ B. sempervirens 'Suffruticosa' } \\
\hline A $T$ r & No symptoms & No symptoms & $>40$ & $<3$ \\
\hline B & High & No symptoms & $32.6 \pm 1.9$ & $443 \pm 410$ \\
\hline $\mathrm{C}$ & High & High & $21.8 \pm 0.3$ & $194,824 \pm 39,124$ \\
\hline
\end{tabular}

${ }^{x}$ Plant samples without (A and B) or with symptoms (C) were collected from asymptomatic plants (A) or diseased plants (B and C). Severity scoring of High to Very low was based on a visual assessment of the symptoms. Plants in the corresponding classes were scored for disease incidence as well as average size of the lesions (as a percentage of the total area of a leaf). These data were used to calculate the estimated percentage of diseased leaf area and roughly corresponded to $25 \%$ for High, $2.5 \%$ for Medium, 1.25 for Low, $0.5 \%$ for Very Low, and $0 \%$ for No symptoms.

y Threshold cycle $(\mathrm{Ct}) \pm$ standard deviation (stdev).

${ }^{\mathrm{z}}$ Amount of $C$. buxicola genomic DNA (gDNA) detected per $50 \mathrm{ng}$ of total DNA (host plant + C. buxicola gDNA). 
pDNA $_{\text {TUB }}$ and gDNA using the TUB SYBR Green construct can be estimated to be 20 targets of pDNATUB (theoretical $\mathrm{Ct}$ value of 29.9) and $750 \mathrm{fg}$ of gDNA (theoretical Ct value of 32.2 ). This is in accordance with the SYBR Green assay (Fig. 1), in which the TUB SYBR Green construct amplified $100 \mathrm{pDNA}_{\text {TUB }}(\mathrm{Ct}$ value of 27.4) but not $10 \mathrm{pDNA}_{\mathrm{TUB}}(\mathrm{Ct}$ value $>40)$ and $10^{3} \mathrm{fg}$ of gDNA (Ct value of 31.7) but not $10^{2} \mathrm{fg}$ of gDNA (Ct value $>40$ ).

In addition to the development of qPCR assays, we also developed methods to process plant, water, and air samples of practical size. Because the ITS qPCR assay was most sensitive, we decided to use this assay for the detection of $C$. buxicola conidia in environmental samples. The potential to detect the latent presence of $C$. buxicola in plant samples was tested using both the ITS TaqMan and TUB SYBR Green constructs. The TUB SYBR Green construct is a less sensitive but cheaper alternative.

The concentration of $C$. buxicola conidia in water samples via centrifugation proved to be an efficient process, with approximately $95 \%$ recovery of conidia after each cycle. Although a $10-\mathrm{ml}$ water sample from a puddle is already sizeable, it was possible to process even larger volumes of clear water samples, such as from rain traps, without significant loss of sensitivity. However, when water samples contain substantial fractions of soil (exceeding the 100- $\mu$ l limit of the PS kit) it might be necessary to take subsamples. Alternatively, filtering the water sample through a $125-\mu \mathrm{m}$ sieve might eliminate the larger soil particles without substantial loss of conidia. The developed sampling protocol proved to be very efficient in detecting conidia in water samples. The assay was very sensitive, with detection of 0.5 -conidium equivalents (one $C$. buxicola genome) per PCR reaction, in both clear and turbid samples, at $\mathrm{Ct}$ values of 33.4 and 35.7, respectively. Although this sampling protocol has been specifically developed toward the detection of $C$. buxicola conidia in water samples for the purpose of researching short-distance dispersal, it is possible to interpret "water samples" more flexibly. For instance, contaminated pruning tools could be rinsed with water and these water samples could be analyzed to test the relative importance of this potential pathway of spread. Rinsing of bird feathers and feet or insects following contact with diseased Buxus plants could substantiate the claims that these animals may be possible vectors of spread.

Similar to water samples, we developed a protocol for processing air samples obtained using a Burkard volumetric spore trap. This protocol was validated using Melinex tape parts representing 12-h sampling periods, because this tape length guaranteed a sufficiently large sampling volume (7,200 liters per $12 \mathrm{~h}$ ) while still allowing overlap-free placement of the tape fragment in the microcentrifuge tubes. In this assay, 10 conidia per tape fragment were reliably detected using the ITS TaqMan assay at a Ct value of 33.9. However, based on the calculated amount of ITS targets and the determined LOD for pDNA $_{\text {ITS }}(\mathrm{Ct}$ value of 37.0), this assay should be able to detect about 3 to 4 conidia per tape fragment.

In our tests with plant samples, leaves were mixed in a large volume of buffer to obtain a representative subsample from a relatively large sample (20 g). Eventually, each subsample contained $100 \mathrm{mg}$ of plant material, being $0.5 \%$ of the original plant sample, which is standard in comparable studies (2). Using the ITS TaqMan qPCR assay and $50 \mathrm{ng}$ of total gDNA extract, $C$. buxicola could still be detected in plant samples in which only $1 \mathrm{ppm}$ of the material was diseased, at a $\mathrm{Ct}$ value of 32.3. Although not tested, it should be possible to even detect $0.1 \mathrm{ppm}$ of infected plant material using the ITS TaqMan construct, because $10 \mathrm{fg}$ of gDNA was confirmed as a reliable LOD for gDNA at a $\mathrm{Ct}$ value of 37.4 (see above). This theoretical LOD of infected plant material in a plant sample seems superior in comparison with similar studies $(2,19)$ that report detection limits of infected plant tissue at $10 \mathrm{ppm}$. At a $\mathrm{Ct}$ value of $13.3,100 \%$ infected leaf material was detected, which was slightly higher than the theoretically calculated $\mathrm{Ct}$ value of 12.6. This raise in $\mathrm{Ct}$ value was probably caused by co-extracted PCR inhibitors, which are present in larger concentrations in fully symptomatic plant material (44). Therefore, for the analysis of such plant material, it may be advisable to use a smaller amount of plant material in the DNA extraction or to dilute the DNA in cases where quantitative data are required. The theoretical $\mathrm{Ct}$ value of 12.6 for fully symptomatic material corresponds to $34.5 \mathrm{ng}$ of $C$. buxicola gDNA, or $69 \%$ of the $50 \mathrm{ng}$ of total gDNA (pathogen + plant host) used in the qPCR reaction. This high percentage of $C$. buxicola gDNA in diseased boxwood leaves is probably caused by the density of the mycelium and microsclerotia of $C$. buxicola in the infected tissues (16).

As expected, the TUB SYBR Green construct was less sensitive, with a reliable detection limit for infected plant material of $10 \mathrm{ppm}$ at a $\mathrm{Ct}$ value of 30.6, which is in the range of the theoretically predicted LOD (750 of fg of gDNA, Ct value of 32.2). Although less sensitive than the ITS TaqMan assay, using the TUB SYBR Green construct in combination with this plant-processing protocol still seems to ensure a degree of sensitivity comparable with that in other studies with ITS-based qPCR assays $(2,19)$. This is probably due to the relatively high proportion of $C$. buxicola DNA in diseased boxwood leaves and the relatively low amounts of PCR inhibitors, allowing the addition of a high concentration of total gDNA.

Because of differences in sensitivity and specificity, three qPCR assays were developed, validated, and tested for their applicability. Each qPCR assay has advantages and disadvantages; the most appropriate construct depends on the needs at hand. If there is no requirement for complete specificity (for instance, when working exclusively with $C$. buxicola under lab conditions), using the ITS SYBR Green construct F492/R621 is recommended because of its superior sensitivity and low cost. Possible applications using this construct include research toward the speed and extent of latent $C$. buxicola development following artificial inoculation of test plants. Different Buxus spp. and cultivars or climatic conditions (temperature and relative humidity) could be tested, adding to the knowledge of host plant susceptibility or weather-dependency, respectively. Research toward the epidemiology of the pathogen depends on the processing of environmental air and water samples, in which case a certain degree of specificity is necessary. The developed ITS TaqMan construct has a very high sensitivity, combined with a good, although not perfect, specificity. It is doubtful, however, if this incomplete specificity has any repercussions on the utility of the TaqMan ITS assay for further use in scientific research. No Cylindrocladium spp. other than $C$. buxicola and $C$. ilicicola (10) has been reported on Buxus spp. yet. Although the specificity of the ITS TaqMan construct has not been tested for $C$. ilicicola, this Cylindrocladium sp. (GenBank accession code FR694681) has the same two-nucleotide mismatch which also guaranteed the specificity toward C. pauciramosum, C. colhounii, and $C$. scoparium. Although it is theoretically possible that a onemismatch Cylindrocladium sp., such as $C$. parasiticum, sporulates on nearby plants, it is very unlikely that environmental samples will get contaminated because very high concentrations are needed to reach their detection limit. However, we still recommend checking for potential host plants of those species in the vicinity of the research site and testing for infection with these Cylindrocladium spp. Last, for diagnosis or for epidemiologic research in which complete specificity is essential, we recommend using the TUB SYBR Green construct F250/R462. This construct comprises the best specificity, albeit at lower sensitivity. Although this lower sensitivity is probably still sufficient to detect latent presence of $C$. buxicola in plants, it can miss marginal amounts of conidia in environmental air and water samples, which limits its utility for performing epidemiology research.

The applicability of the techniques to water, air, and plant samples of practical size was demonstrated. Although such samples were only processed for that purpose in this work, the results reveal interesting preliminary data regarding the epidemiology of the pathogen. High concentrations of C. buxicola were demonstrated in all water samples whereas $C$. buxicola was only confirmed occasionally and at very low concentrations in air samples. These results indicate that $C$. buxicola is a water- rather than a wind-dispersed pathogen, consistent with assumptions in other publications 
(27). Analysis of plant samples demonstrated the applicability of these tools to different Buxus spp. and cultivars, with a very good linear correlation between detected amounts of gDNA and disease severity, making this protocol also a useful tool for the quantification of disease development. In addition, we demonstrated that the protocol is able to detect $C$. buxicola in boxwood plants in latent stages of disease development.

\section{Acknowledgments}

This research was financed via project 080519 of the Agency for Innovation by Science and Technology (IWT, Belgium) and its industry supporters. We thank B. Henricot, K. Van Poucke, and J. Debode for providing isolates; and M. Levenson for English language editing.

\section{Literature Cited}

1. Akilli, S., Katircioglu, Y. Z., Zor, K., and Maden, S. 2012. First report of box blight caused by Cylindrocladium pseudonaviculatum in the Eastern Black Sea region of Turkey. New Dis. Rep. 25:23.

2. Alaei, H., Baeyen, S., Maes, M., Höfte, M., and Heungens, K. 2009. Molecular detection of Puccinia horiana in Chrysanthemum $\times$ morifolium through conventional and real-time PCR. J. Microbiol. Methods 76:136-145.

3. Batdorf, L. R. 1997. Boxwood Handbook: A Practical Guide to Knowing and Growing Boxwood. The American Boxwood Society, Boyce, VA.

4. Batdorf, L. R. 2004. Boxwood : An Illustrated Encyclopedia. The American Boxwood Society, Boyce, VA.

5. Benko Beloglavec, A., Ličen, R., Seljak, G., Šnajder Kosi, K., Grando, Z., Lešnik, M., and Pavlič Nikolič, E. 2009. New pests detected on plants moved from member states of the European Union or during the production in Slovenia in 2008. Abstr. 138. 9th Slovenian Conf. Plant Prot., Nova Gorica.

6. Bir, R. E., Bilderback, T. E., Baker, J. E., and Jones, R. K. 2012. Commercial boxwood Production. Last accessed September 18, 2012, http://www.ces.ncsu.edu/depts/hort/hil/hil-407.html

7. Borneman, J., and Hartin, R. J. 2000. PCR primers that amplify fungal rRNA genes from environmental samples. Appl. Environ. Microbiol. 66:4356-4360.

8. Boyle, B., Hamelin, R. C., and Seguin, A. 2005. In vivo monitoring of obligate biotrophic pathogen growth by kinetic PCR. Appl. Environ. Microbiol. $71: 1546-1552$.

9. Brand, T. 2005. Occurrence of Cylindrocladium buxicola B. Henricot on boxwood in Northwest-Germany. Nachrichtenbl. Dtsch. Pflanzenschutzdienstes (Berlin) 12:237-240.

10. Brayford, D., and Chapman, A. U. 1987. Cylindrocladium ilicicola on cutting of evergreen ornamental shrubs in the UK. Plant Pathol. 36:413-414.

11. Bustin, S. A., Benes, V., Garson, J. A., Hellemans, J., Huggett, J., Kubista, M., Mueller, R., Nolan, T., Pfaffl, M. W., Shiley, G. L., Vandesompele, J., and Wittwer, C. T. 2009. The MIQE guidelines: minimum information for publication of quantitative real-time PCR experiments. Clin. Chem. 55:611622.

12. CABI. 2007. Distribution Maps of Plant Diseases. Cylindrocladium buxicola Henricot. Map No. 996, edition 1. CABI and EPPO, Wallingford, UK.

13. Cech, T., Diminic, D., and Heungens, K. 2010. Cylindrocladium buxicola causes common box blight in Croatia. Plant Pathol. 59:1169.

14. Collins, A., Okoli, C. A. N., Morton, A., Parry, D., Edwards, S. G., and Barbara, D. J. 2003. Isolates of Verticillium dahliae pathogenic to crucifers are of at least three distinct molecular types. Phytopathology 93:364-376.

15. Crepel, C., and Inghelbrecht, S. 2003. First report of blight on Buxus spp. caused by Cylindrocladium buxicola in Belgium. Plant Dis. 87:1539.

16. Crous, P. W., Groenewald, J. Z., and Hill, C. F. 2002. Cylindrocladium pseudonaviculatum sp. nov. From New Zealand, and new Cylindrocladium records from Vietnam. Sydowia 54:23-34.

17. Crous, P. W., Groenewald, J. Z., Risede, J. M., Simoneau, P., and HywelJones, N. L. 2004. Calonectria species and their Cylindrocladium anamorphs: species with sphaeropedunculate vesicles. Stud. Mycol. 50:415430.

18. Dart, N., Hansen, M. A., and Bush, E. 2011. Boxwood Blight: a New Disease of Boxwoods Recently Found in the Eastern U.S. http://www.vdacs. virginia.gov/plant\&pest/pdf/boxwoodblight.pdf

19. Debode, J., Van Hemelrijck, W., Baeyen, S., Creemers, P., Heungens, K., and Maes, M. 2009. Quantitative detection and monitoring of Colletotrichum acutatum in strawberry leaves using real-time PCR. Plant Pathol. 58:504-514.

20. Debode, J., and Van Poucke, K. 2011. Detection of multiple Verticillium species in soil using density flotation and real-time polymerase chain reaction. Plant Dis. 95:1571-1580.

21. EPPO. 2004. EPPO Reporting Service: Cylindrocladium buxicola is a new disease of Buxus: addition to the EPPO Alert List. Rep. No. 123.

22. EPPO. 2010. EPPO Reporting Service: Incursions of Cylindrocladium buxicola in Austria. Rep. No. 143.
23. EPPO. 2012. EPPO Reporting Service: First report of Cylindrocladium buxicola in the Czech Republic. Rep. No. 059.

24. Gardes, M., and Bruns, T. D. 1993. ITS primers with enhanced specificity for basidiomycetes - application to the identification of mycorhizae and rusts. Mol. Ecol. 2:113-118.

25. Gorgiladze, L., Meparishvili, G., Sikharulidze, Z., Natsarishvili, K., and Davitadze, R. 2011. First report of box blight caused by Cylindrocladium buxicola in Georgia. New Dis. Rep. 23:24.

26. Groen, B., and Zieleman, W. 2012. Problemen met buxus en mogelijke vervangers. Groen 67:10-16.

27. Henricot, B. 2006. Box blight rampages onwards. Plantsman 5:153-157

28. Henricot, B., and Culham, A. 2002. Cylindrocladium buxicola, a new species affecting Buxus spp., and its phylogenetic status. Mycologia 94:980997.

29. Henricot, B., David, J., Ivors, K., Heungens, K., Spooner, B., Pérez Sierra, A., and Daughtrey, M. L. 2012. Proposal to conserve the name Cylindrocladium buxicola against $C$. pseudonaviculatium (Ascomycota). Taxon 61:1119-1120.

30. Henricot, B., Gorton, C., Denton, G., and Denton, J. 2008. Studies on the control of Cylindrocladium buxicola using fungicides and host resistance. Plant Dis. 92:1273-1279.

31. Huvenne, H., Debode, J., Maes, M., and Heungens, K. 2011. Real-time PCR mediated monitoring of Fusarium foetens in symptomatic and nonsymptomatic hosts. Eur. J. Plant Pathol. 131:705-717.

32. Inghelbrecht, S., Gehesquiere, B., and Heungens, K. 2011. First report of Calonectria leaf spot caused by Calonectria colhounii (anamorph Cylindrocladium colhounii) on Rhododendron in Belgium. Plant Dis. 95:1477.

33. Ivors, K., and LeBude, A. 2011. A new pest to the U.S. Ornamental Industry: The "box blight" pathogen Cylindrocladium pseudonaviculatum $=\mathrm{Cyl}$ indrocladium buxicola. http://www.hgic.umd.edu/content/documents/NC pestalertboxblight.pdf

34. Kubista, M., Andrade, J. M., Bengtsson, M., Forootan, A., Jonak, J., Lind, K., Sindelka, R., Sjöback, R., Sjögreen, B., Strömbom, L., Tahlberg, A., and Oric, N. 2006. The real-time polymerase chain reaction. Mol. Asp. Med. 27:95-125.

35. Kutyavin, I. V., Afonina, I. A., Mills, A., Gorn, V. V., Lukhtanov, E. A., Belousov, E. S., Singer, M. J., Walburger, D. K., Lokhov, S. G., Gall, A. A. Dempcy, R., Reed, M. W., Meyer, R. B., and Hedgpeth, J. 2000. 3'-Minor groove binder-DNA probes increase sequence specificity at PCR extension temperatures. Nucleic Acids Res. 28:655-661.

36. Larson, P. D. 1996. Boxwood: Its History, Cultivation, Propagation and Descriptions. Foliar Press, Boyce, VA.

37. Lee, S. B., and Taylor, J. W. 1992. Phylogeny of five fungus-like protoctistan Phytophthora species, inferred from the internal transcribed spacers of ribosomal DNA. Mol. Biol. Evol. 9:636-653.

38. Lombard, L., Crous, P. W., Wingfield, B. D., and Wingfield, M. J. 2010. Phylogeny and systematics of the genus Calonectria. Stud. Mycol. 66:3169.

39. Milius, S. 2012. Boxwood Blight invades North America. http://www.sci encenews.org/view/generic/id/33795/title/Boxwood_blight_invades_North_ America

40. O'Donnell, K., and Cigelnik, E. 1997. Two divergent intragenomic rDNA ITS2 types within a monophyletic lineage of the fungus Fusarium are nonorthologous. Mol. Phylogenet. Evol. 7:103-116.

41. Ridley, G. 1998. New plant fungus found in Auckland box hedges (Buxus) For. Health News 77.

42. Saracchi, M., Rocchi, F., Pizzatti, C., and Cortesi, P. 2008. Box Blight, A New Disease of Buxus in Italy Caused by Cylindrocladium buxicola. J. Plant Pathol. 90:581-584.

43. Saurat, C., Fourrier, C., and Ioos, R. 2012. First Report of Blight Disease on Buxus caused by Cylindrocladium buxicola in France. Plant Dis. 96:1069.

44. Singh, R. P., Singh, M., and King, R. R. 1998. Use of citric acid for neutralizing polymerase chain reaction inhibition by chlorogenic acid in potato extracts. J. Virol. Methods 74:231-235.

45. Van Trier, H., and Hermans, D. 2005. Buxus. Stichting kunstboek, Oostkamp, Belgium

46. Varela, C. P., Penalta, B. G., Vazquez, J. P. M., and Casal, O. A. 2009. First report of Cylindrocladium buxicola on Buxus sempervirens in Spain. Plant Dis. 93:670.

47. Vincent, M. 2008. Cylindrocladium buxicola, une nouvelle maladie du buis. ACL 2008/4. Les nouveaux ravageurs et maladies des plantes cultivées en Suisse.

48. Whelan, J. A., Russell, N. B., and Whelan, M. A. 2003. A method for the absolute quantification of cDNA using real-time PCR. J. Immunol. Methods 278:261-269.

49. White, T. J., Burns, T., Lee, S., and Taylor, J. 1990. Amplification and direct sequencing of fungal ribosomal RNA genes for phylogenetics. Pages 315322 in: PCR Protocols: A Guide to Methods and Applications. M. A. Innis, D. H. Gelfand, J. J. Shinsky, and T. J. White, eds. Academic Press, San Diego, CA. 